\title{
The management of the plague in Florence at the beginning of the Renaissance: The role of the partnership between the Republic and the Confraternita of Misericordia
}

\author{
Giacomo Manetti, Marco Bellucci \\ and Luca Bagnoli \\ University of Florence, Italy
}

\begin{abstract}
The role of charities in the administration of health care and poverty, and the use of accounting in their control mechanisms, is a relatively unexplored topic in the accounting history literature. This study aims to enrich the literature by studying how accounting systems were used in the management of the plague by a charity organisation - the Confraternita of Misericordia - during the first decades of the Renaissance in Florence, focusing on the role of the partnership between the Republic of Florence and the Misericordia. This research is the result of the analysis of rare documents, statutes and account books concerning the administration of the Misericordia from 1490 to 1530. Our analysis employs Foucault's theories on the 'government of the poor' and Dean's thoughts on 'technologies of government' and 'policing the poor' to highlight the link between religious values, political power and the accountability practices of the Misericordia.
\end{abstract}

\section{Keywords}

accounting, Florence, government of the poor, Misericordia, plague, Renaissance, technologies of government

\section{Introduction}

Since the fifteenth and sixteenth centuries, public authorities have faced the problem of poor relief (Fouarge, 2004; Servalli, 2013). Scholars have devoted great efforts to studying government policies that were directed towards the poor, often emphasising the role of charitable organisations (Black, 1989; Cohen, 2005a, 2005b; Critchlow and Parker, 1998; Kelly and O'Gráda, 2011; McIntosh, 2005; Van Leeuwen, 1994). During the last part of the Middle Ages and the first decades

\section{Corresponding author:}

Giacomo Manetti, Department of Economics and Management, University of Florence, Via delle Pandette, 9, 50127 Florence, Italy.

Email: giacomo.manetti@unifi.it 
of the Renaissance, local governments frequently enacted poor relief policies in which charities and non-profit organisations (NPOs) played a fundamental role, influencing the lives of many through assistance activities and the management of health emergencies (Servalli, 2013; Van Leeuwen, 1994). However, the role of NPOs in the administration of health care and poverty alleviation and the use of accounting in their control mechanisms is still a relatively unexplored topic in the accounting history literature (Sargiacomo and Gomes, 2011; Servalli, 2013).

This study aims to enrich the literature by studying how accounting systems were used in the management of the plague by a charity organisation during the first decades of the Renaissance in Florence, Italy. To achieve this objective, this study examines the Confraternita della Misericordia - the Confraternity of Mercy - which was entrusted by the City of Florence to offer health services after the plague re-emerged in 1498 .

Specific accounting systems were implemented by the Misericordia in order to record the operational activities and financial transactions related to plague assistance. The details of this process were stated in a section of a statute from 1501 titled 'When the time of plague occurs'. These documents reveal that the Republic of Florence granted the Misericordia, a private charity, an important role in providing public health services to the local community, while also providing them with public funding that the Misericordia had to manage separately from other funds.

According to Henderson (1994), the Confraternita of Misericordia was a charitable society that provided poor relief in an urban setting. These types of private institutions were found throughout medieval Europe under the Misericordia in Italy and Spain, the Tables of the Holy Ghost in Belgium and the Charités and Aumônes in France (Eckstein, 2004; Gazzini, 2012; Henderson, 1994: 36; Lee, 2005).

The Misericordia was, therefore, the product of the social and religious traditions of the citizenry (Corbellini and Hoogvliet, 2013; Henderson, 1994). The confratelli ('Confraternity members') practised charity and offered many services, including the management of hospitals and burying the dead. In other words,

the works of the Misericordia, following the evangelical pattern by Matthew 25, were one of the hinges of the Confraternity action; these associations in the Middle Ages added to the other six evangelic works of the Misericordia, a seventh one: the burial of the dead. (Paglia, 1984)

In Europe, particularly Italy and Spain, the Confraternities represented a means through which the citizenry could participate in the social and political life of the community. They helped settle arguments between civil and religious authorities and fill the gaps within the hierarchy of the Church, especially between monks and the community of believers (Paglia, 1984). Constantly keeping the balance between the suspicions of heresy, on religious side, and the political power on civil side, the Confraternities, often very rich because of the donations and legacies, have become the most common voluntary associations in Europe starting from the fourteenth century.

Although this study is based on the national and international accounting history literature, it also contributes to historiographical debates involving the social, political, cultural and medical contexts in the Republic of Florence at the beginning of the Renaissance. Accounting is a social science that is concerned with the systematic arrangement of social phenomena. Thus, as accounting historians, we are obliged to consider the broader social implications of our discipline (Gaffikin, 2011; Parker, 1999). Unfortunately, the scholarly literature on this topic rarely examines the role of charities in providing public services during the Renaissance period.

This study will introduce and discuss the theoretical framework we used as a means of analysing our archival sources (sections 'Theoretical framework' and 'Sources'). Sections 'The origins of the Misericordia in Florence' and 'Misericordia and accounting for the plague' will retrace the main 
phases of the Misericordia's history, from its establishment until the beginning of the Renaissance, and describe the primary differences between the statutes of the Misericordia in 1490 and 1501 and the main characteristics of the agreement (the provision) signed by the Republic of Florence and the Misericordia for providing assistance to victims of the plague. This involves analysing the original accounting books and documents contained in the historical archives of the Misericordia in order to explain the accounting processes used in recording the various operations related to the management of the plague. Section 'Discussion' discusses the role of the provision and Misericordia's accountability practices as 'technologies of government', placing emphasis on how religious values and principles deeply affected human behaviours, especially among charities. Finally, in the section 'Conclusion', we formulate conclusions on the role played by the Misericordia and its accountability systems in managing the plague emergency and outline future avenues of research.

\section{Theoretical framework}

This study adopts the concept of 'governmentality', which was originally elaborated by Foucault at the beginning of the 1980s. Special attention is given to his ideas on the 'government of the poor' (Foucault, 2010). Foucault encourages us to think of power not only in terms of the hierarchical, top-down power of the state but also the forms of social control that are employed by institutions (churches, schools and hospitals) and through various forms of knowledge. Power can manifest itself positively by producing knowledge and certain discourses that get internalised by individuals and guide their behaviour. This leads to more efficient forms of social control, as knowledge enables individuals to govern themselves. According to Foucault (1991), this includes the management of adverse situations which require a government of 'men in their relation to that other kind of things, accidents and misfortune such as famine, epidemics, death, etc.' (p. 93). Rose and Miller (1992: 181) point out that these types of difficulties often motivate government responses because reality is a domain the authorities can act upon by planning and implementing interventions (Riccaboni et al., 2006; Rose and Miller, 1992: 183; Servalli, 2013: 1311).

Foucault argued that 'government' was defined in an entirely different manner during the early Renaissance, oftentimes emphasising self-conduct or self-government (Foucault, 2007). Thus, the essential element of a ruler is

often presented unchallenged to the populace as a system of unimaginable alterations, self-perpetuating and self regularity (among those who inhabit the system), where clearly defined roles are defined and repeated right throughout the system (through norms). (pp. 11-13)

Foucault associated this type of 'pastoral' power with the Christian Church, since it has operated for about fifteen centuries as the ruler of society in much of Europe. This also implied struggles for the supremacy in this type of pastoral power and in the government over men and their souls. According to Foucault, the Church used its power to condition the citizenry in their day-to-day lives by referring to age-old ideas on personal salvation. Foucault considered the police as an instrument of power that was connected to education, welfare, poverty, organisation of the market, government and medicine (Elden, 2003: 247-248). The police were something more than a simple means of preventing and detecting crimes.

Inspired by Foucault (1984a: 241, 2009: 312), Dean (1992) argued that the "the police of the poor' (pp. 223-228) was an

ensemble of mechanisms serving to ensure order, the properly channelled growth of wealth and the conditions of preservation of wealth 'in general'. (Foucault, 1984b: 277) 
During the Middle Ages and the first decades of Renaissance, in particular, one can identify a 'conservative' phase of policing that sought to maintain a society of orders and estates (Dean, 1992: 225). In continental Europe, policing was left to a diverse array of actors (Dean, 1992: 224), including charities (Minson, 1985: 104-105) that were in almost all cases inspired by faith and linked to the Church.The poor, understood as a general category, were a fundamental object of this form of policing (Dean, 1991: 57). In fact, the people and institutions responsible for policing the poor often saw the underclass as an object of observation, comparison and information collection (Dean, 1992: 227). According to Miller and Rose (1990: 7-8), the government is based on what is to be governed ('forms of knowledge') and on specific forms of intervention ('regimes of practices').

A political rationality is particular representation of the reality based on the intellectual processing of the reality itself that 'technologies of government' can deal with (Lemke, 2001: 191), implying the involvement of agencies, procedures, institutions and even charities in specific historical periods. Within the cited mechanisms for realising 'the police of the poor' according to a specific 'political rationality', Dean (1996) identifies different kinds of punishment, caring, assisting and schooling that are included in the umbrella expression 'technologies of government' (p. 52). According to Dean, 'practical rationalities' and 'specialist knowledge' are typical technologies of government. Servalli (2013) defines 'practical rationalities' as 'programmes, policies and plans that reflect on technology, defining its acting in relation to defined aims' (p. 1313). Through these mechanisms, authorities try to shape, normalise and conform to their expectations the thoughts, behaviours and actions of citizens and other organisations in order to achieve their aims (Miller and Rose, 1990: 8).

The existence of these policies and techniques can be better understood as 'technological thresholds' (Dean, 1996: 63). These 'thresholds' are signs of government technology and can be divided into four categories:

- The 'threshold of assemblage': an assemblage of different elements for conducting government activity, such as inscription devices for the production and use of information, means for creations of authority forms, mechanisms for a space/time coordination, physical forms of divisions and 'practical rationalities' expressed by specific policies investing technologies and needing specialist knowledge;

- The 'threshold of system': the necessary link between the technology of government and other kinds of technologies (production, consumption and communication) in order to influence objects, people, capabilities, sources and communication networks;

- The 'threshold of force': the realisation of sites as power containers, stores or generators that is, places for the independent generation of goods, energy, information and services and forms of social authority, regulation and control;

- The 'threshold of the orientation of government': forces and capabilities of subjects, groups or populations, as elements to improve and optimise (Dean, 1996: 63-64).

Techniques of notation, accounting, assessment and reporting represent typical tools used by central and local authorities for creating a 'government of the poor' (Rose and Miller, 1992: 183) and can be considered among the 'thresholds of government'. Thus, book-keeping, registers and formalised models of health care and assistance can be considered signs and forms of 'technology of government' (Rose and Miller, 1992: 177-178).

At the same time, according to Quattrone (2004) and Servalli (2013), accounting and accountability practices among charities inspired by religious values cannot be reduced to financial control mechanisms that measure an organisation's financial performance and assets. On the contrary, the development of accounting and accountability practices was linked to the values of the Church, which were shaped by various religious, political, institutional and social factors (Booth, 1993). 
The development of accountability practices in charities inspired by religious values cannot be reduced to a single economic argument (Quattrone, 2004). Accounting practices in charitable organisations during the Middle Ages were not only the result of a search for efficiency, the product of a simple economic rationale, but rather the pursuit of models compliant with Church doctrine and policy. At the same time, doctrinal considerations were the products of a

complex and continuous process of compromise among theological, religious, political, institutional, and social pressures, of which the hierarchical structure of charitable organisations and their accounting records constituted the remaining visible trace. (Quattrone, 2004: 649)

The centrality and special nature of religious belief systems is thus one of the key explanatory factors in understanding accounting as a situated practice in religious entities (Booth, 1993). Some parts of the accounting literature have begun to give specific attention to accountability practices in religious entities (cf. Booth, 1993; Quattrone, 2004; Servalli, 2013). However, since the number of studies on this topic remains relatively low compared to the number of studies that address the social significance and pervasiveness of religious institutions (Booth, 1993), it is safe to say that most research on this topic has often treated religious entities as belonging to a broader sector of NPOs. Unfortunately, this means that religious values often go unaddressed among those who study accounting and accountability practices (Booth, 1993; Quattrone, 2004).

\section{Sources}

In order to pursue our research objective, we opted for a qualitative approach that is based on historical analysis and involves documents and other artefacts that can be used to trace the history of a specific organisation (Bryman and Bell, 2015). According to Munslow (2007: 20), the 'rational, independent and impartial investigation' of historical documents represents one of the most valuable aspects of the historian's work. Moreover, we believe that archival research is the most appropriate approach to our specific research objective (Fleischman and Tyson, 1997; Gaffikin, 2011). The findings presented in this study are based on the examination of the primary and secondary sources shown in Tables 1 and 2, respectively.

Table I. Primary sources.

\begin{tabular}{|c|c|c|}
\hline Primary sources & Year & Main contents used for this study \\
\hline $\begin{array}{l}\text { The Statute of the } \\
\text { 'New' Misericordia }\end{array}$ & 1490 & $\begin{array}{l}\text { Analysis of governing bodies, their composition and the rotation } \\
\text { rules of the diverse offices and figures. }\end{array}$ \\
\hline $\begin{array}{l}\text { The revised version } \\
\text { of the Statute of the } \\
\text { Misericordia }\end{array}$ & $150 \mid$ & $\begin{array}{l}\text { Analysis of the chapter 'In time of sickness' (chapter XVI) on the } \\
\text { management of the plague. It contains the accounting guidelines } \\
\text { defined by the brotherhood for the 'Superintendent of the } \\
\text { Sickness', the external depositary who managed the overall } \\
\text { funding for the treatment of the outbreak and the various } \\
\text { suppliers of food and other necessities. }\end{array}$ \\
\hline $\begin{array}{l}\text { The provision between } \\
\text { the Republic of Florence } \\
\text { and the Confraternita of } \\
\text { Misericordia }\end{array}$ & 1499 & $\begin{array}{l}\text { Through this provision, the Republic agreed to provide the } \\
\text { Misericordia with periodic payments by levying taxes on } \\
\text { salt, wine and contracts that were established by the town's } \\
\text { camerlinghi (chamberlains). }\end{array}$ \\
\hline $\begin{array}{l}\text { Superintendent's } \\
\text { register }\end{array}$ & $1522-24$ & \multirow{2}{*}{$\begin{array}{l}\text { Study of the management of the funds for the treatment and } \\
\text { prevention of the disease, with particular focus on the role of the } \\
\text { depositary as an external and independent trust. }\end{array}$} \\
\hline Depositary's register & $1522-24$ & \\
\hline
\end{tabular}


Table 2. Secondary sources.

\begin{tabular}{|c|c|}
\hline Secondary sources & Main contents used for this study \\
\hline $\begin{array}{l}\text { Affolter and Rossi (20I5) } \\
\text { Carmichael (I986) } \\
\text { Cipolla (1976) } \\
\text { Della Stufa (I528) } \\
\text { Diana (20I4) } \\
\text { Henderson (1987) } \\
\text { Henderson (1994) } \\
\text { Torricelli (20|4) }\end{array}$ & $\begin{array}{l}\text { Analysis of the management of the plague during the first } \\
\text { decades of the Renaissance with specific reference to the } \\
\text { role of the Misericordia in poverty alleviation and as a } \\
\text { health-care provider. }\end{array}$ \\
\hline
\end{tabular}

The primary sources in Table 1 (registers, statutes and the provision) are part of the category of 'technologies of government' and more specifically the sub-category of 'practical rationalities'. In particular, the registers and the provision can be considered among the 'thresholds of government'. However, the diverse versions of the statute provide interesting information on the role played by religious values, which represent key explanatory factors in understanding accounting as a situated practice in the Confraternita of Misericordia.

Primary sources are currently preserved in the archives of the Misericordia, with the exception of the original agreement (the provision) between the Republic of Florence and the Misericordia, which is preserved in the Archivio di Stato of Florence. These sources, together with the secondary sources listed in Table 2, allow us to examine the historical, institutional and organisational contexts encountered by the Misericordia while managing the plague emergency system in the Republic of Florence. Thus, secondary sources were used for understanding how various historical, religious, political, institutional and social factors (Booth, 1993) influenced the development of accounting and accountability practices in the Confraternita and, more broadly, in the Republic of Florence according to the model of 'government of the poor'.

The process of interpreting the archival documents was aided by two expert archivists from the Tuscan Archival Superintendence. The archivists supported us in reading the documents - which are written in the specific vernacular used in Florence during Renaissance - and provided us with many insights on the history of the Misericordia of Florence. Every relevant part of the documents was photographed and transcribed in order to support our research question and present a strong case for our theoretical framework, which is based on the concepts of governmentality, policing the poor and the link between accountability practices and religious values.

The sources shown in Tables 1 and 2 enabled us to understand how the Republic of Florence employed the specific services of the Misericordia, appealing to the 'professional skills' and values of its members to manage the plague emergency. At the same time, our primary and secondary sources allowed us to understand the system of internal accountability that the Misericordia adopted as a means of avoiding misconduct, guaranteeing transparency and respecting the moral and religious values of the statute. Special emphasis was placed on Foucault's and Dean's concepts of 'government of the poor', 'technologies of government' and 'technological thresholds'.

\section{The origins of the Misericordia in Florence}

'Venerabile Arciconfraternita della Misericordia di Firenze' (Venerable Confraternity of Misericordia of Florence) is one of the oldest charitable institutions in the world. It was established as a branch of the Society of Faith in Florence in 1244 by Peter of Verona (1205-1252), a Dominican friar who was later sainted and took the name Peter the Martyr (Merlo, 1984). The Society of Faith 
was an institution whose believers, organised in local associations known as 'Miles Fidei' ('Militia of Faith') that were under the command of 12 captains, served to protect the Church from heresy (Golinelli, 1984).

Peter of Verona tried to strengthen the role played by the Church and the laity in the city of Florence, but his activities were observed by the imperial Podestà, who reacted badly to this initiative. The conflicts that arose between the Church, its supporters and the Empire were particularly daunting, involving issues pertaining to civil law, municipal administration, religious values and obedience to the faith (Bargellini, 1980). On St Bartholomew's day (24 August 1244), a group of armed men, patarins and supporters of the Podestà attacked the believers in Santa Reparata cathedral, resulting in numerous deaths. In 1245, the 'Society of the Faith' then split into three new companies (Donnelly and Maher, 1999): (1) the Company of the Virgin, which then changed its name to the Company of Saint Peter the Martyr. Peter of Verona was killed in 1252 near Seveso by a group of heretic patarins and was declared a saint in 1253 (Torricelli, 2014); (2) the Company of the Bigallo; and (3) the Company of the Misericordia.

In the early years, the main activities of the Misericordia of Florence consisted of providing dowries to indigent girls, helping people in need and burying the poor. Later, during the great pestilences that struck Florence from the fourteenth century onwards, the Misericordia also started working on the hazardous transportation of sick people to town hospitals. The provision of these services, which were not otherwise publicly provided, was very important for the entire city of Florence, as donations were made with increasing frequency to the Misericordia thereafter (Tombaccini, 2009). The Brotherhood distinguished itself so much in these tasks that on 31 March 1329, a provision of the township of Florence conferred on the Misericordia the official rank of public institution. In the middle of the fourteenth century, the Republic of Florence, following the lead of other European countries, began to pay more attention to the Confraternities, adopting an undeclared aim of handling its estates and influencing its social policy (Henderson, 1994). This was made possible because many captains from various companies searched for 'political protection' and new 'opportunities' for their organisations in order to obtain new funds and visibility (Little, 1988). Many important Florentine public figures were involved in the activities of the Misericordia. For example, the wellknown explorer Amerigo Vespucci was a member of the Confraternita.

In 1425, in order to save the Company of Bigallo from bankruptcy, the Republic decided to merge the Company with the Confraternity of Misericordia, which was in excellent financial shape (Bianchi, 1855). In 1440, the Republic appointed a new 'Camerlingo' (chamberlain) from the Company of Orsanmichele to manage and lead the new united confraternity. The Republic's control over the Confraternity was thus complete.

In 1489, a group of brothers decided to break away from the rest of the Confraternity and establish a rival organisation with a new statute that brought in a host of new members (Weissman, 1982). The new Misericordia of Florence became 'active more than ever in the deeds of mercy' and was completely independent from the Company of Bigallo. The burial of the dead, in particular, was a typical deed of mercy taken up by the new organisation, an activity that had been abandoned during the period of 'forced cohabitation' with the Company of Bigallo.

According to the statute of 1490 , the new confraternity was composed of 72 brothers (30 ministers and 42 secular representatives), like the disciples of Jesus in the Gospel of Luke and by an undefined number of brothers and sisters from the laity - 'the greater number'. The 72 brothers chose 4 captains, 4 counsellors, 2 commissioners and 2 chamberlains. These offices rotated every 4 months until all 72 brothers had assumed at least one role within the organisation. In 1489, however, Lorenzo the Magnificent, together with other members of the Medici family, joined the Misericordia, assuming positions within the brotherhood of the 72 and given 'small number' status, which was very exclusive at the time. Amerigo Vespucci, by contrast, became a member of the 
'greater number', a less exclusive type of membership that was made available to foreigners, women and employees.

After Lorenzo's death in 1492, his son Piero took the reins of government. However, his rule proved brief because Charles VIII of France invaded Italy in 1494, entering Tuscany on his way to claim the throne of Naples. After Piero made a submissive treaty with Charles, the Florentines responded by forcing Piero into exile, and the first period of Medici rule ended with the restoration of a republican government. Anti-Medici sentiment and the birth of the republic (1494-1498) was much influenced by the teachings of the radical Dominican prior Girolamo Savonarola (Najemy, 2008: 390).

When the plague re-emerged in Florence in 1495, the local church granted the Misericordia the task of burying the dead. The bishop and its vicar authorised the Misericordia to bury the dead on land owned by various churches, with or without authorisation from local priests (Brucker, 1998).

Girolamo Savonarola lost support and was burned at the stake in 1498, when the Republic began to be presided over by the 'Gonfaloniere di giustizia'. Piero Soderini, a confidant of the Medici family, was appointed to lead a moderate government shortly thereafter. Its mandate was extended for life in 1502, but Soderini was forced to leave the city in 1512 when Cardinal Giovanni de Medici captured Florence with Papal troops during the War of the League of Cambrai. Medici rule was thus restored (Pesman Cooper, 1967: 145-185).

Even during the years of the Republic, when the Medici family was exiled, the Misericordia kept its prestige intact. However, nobody discussed its role as protector of the faith or mentioned the services it provided to the local community, including transporting sick people and burying the dead when the plague reappeared (Henderson, 1994: 438).

\section{Misericordia and accounting for the plague}

In 1495, during the republic of Savonarola (1494-1498), a new outbreak of plague wreaked havoc within Florence, lasting approximately 4 years. In 1496, the Republic set up a citizens' commission in which the Officials of the Sickness were given the task of managing the emergency. This commission was the natural continuation of the so-called Otto di Guardia e Balia, a group of eight experts nominated in 1448 by the Republic for managing and implementing sickness and infection prevention policies in the town of Florence during the Plague.

This body immediately decided to ask the Confraternity of the Misericordia to assist the sick, recognising the city's limited resources for addressing this kind of calamity (Carmichael, 1986). In subsequent years, the Officials of the Sickness represented the political organ of the Republic in terms of managing plague epidemics. The Misericordia worked with them in delivering a host of services (Arbid, 1838: 467).

Although the Misericordia did not ask for payment in providing services to the sick, the assistance it provided involved considerable costs. For example, it had to provide basic necessities and medicine to the sick, while also paying doctors, surgeons and nurses for their expertise. On 30 July 1499, the Republic, under the government of Soderini, recognised this situation and signed a provision with the Misericordia, agreeing to make periodic monetary payments in the form of taxes on salt, wine and contracts that were levied by the town's camerlinghi (chamberlains).

This agreement guaranteed that 'four small dinari' on every levy collected by the town's camerlinghi would be given to the Captains of the Misericordia on a bi-monthly basis for 3 years. To ensure that these payments were made promptly to the Misericordia, it was decided that in the event of any delay, the camerlinghi should pay double the amount owed to the Confraternity.

A few months later, on 17 March 1500, the Republic decided to increase the payment to 'ten dinari'. The Captains of the Confraternity were also paid monthly instead of every 2 months. To 
this remuneration was added a portion of the monetary payments imposed by the Officials of the Sickness.

To ensure that the transfer of money was done in a transparent manner and in such a way as to avoid creating conflict with the Church, the Republic decided that the payments to the Captains of the Misericordia would not be made directly by the town's camerlinghi but by the camerlingo of the Florentine 'mount of piety', the Republic's official moneylender. This credit institution, according to Henderson (1987: 51), also provided the Misericordia with funding for other activities at particularly favourable rates.

The 1499 provision gave the Misericordia general duties of assisting the needy, both healthy and sick, and burying the dead. In the months that followed, however, the Republic began to outsource to the Misericordia a whole series of functions regarding assistance, increasing its governmentality towards the poor. This was done because they recognised not only the public institution's inability to guarantee assistance but also the superior 'professionalism' of the Confraternity. As a result, the Misericordia began managing the structures for quarantining plague victims. The new lazzaretto di San Bastiano fuori le mura was, in reality, built gradually over subsequent years, as the project was abandoned each time the epidemic was temporarily defeated. The Misericordia also built and maintained wooden huts by the town walls for the isolation of the sick, organised surveillance of suspected cases and gave social and material assistance to the needy (Corsini, 1911; Della Stufa, 1528: 376; Di San Luigi, 1786: 238; Henderson, 1987).

Not long after the reforms of 1490, the Misericordia felt the need to modify its statute in order to better regulate specific activities, including how to respond during outbreaks of the plague. This call for more specific regulations was connected to the changing social structure and needs of the poor in the specific context that Misericordia was operating in. In order to fully recognise its role as 'police of the poor' (Foucault, 1984b), the Misericordia needed new guidelines to provide order and wealth to its beneficiaries while still complying with principles inspired by the Church. In 1501, a new statute included a chapter titled 'In time of sickness' (chapter XVI) on the management of the plague. This chapter is particularly interesting because it contains the accounting guidelines defined by the brotherhood for the 'Superintendent of the Sickness', the external depositary who managed the overall funding for the treatment of the outbreak and the various suppliers of food and other necessities.

The superintendent was expected to keep a register of about 60 pages, which had to be closed at the end of each quarter. All moneys withdrawn from the depositary and all food items received from the suppliers were reported as revenue, while every expense sustained while treating the infected, who become debtors of the Confraternity, were reported as outflow. Detailed instructions that were expected to be followed whenever new epidemics emerged were provided by the new statute.

In case of new epidemics, the 72 brethren, especially the 4 captains, had to all agree on a resolution of intervention in order to assist the population. Following this resolution, the Confraternity was required to nominate a superintendent 'for the sickness' who was dedicated to managing the plague emergency and was chosen from among the clerical brethren. After 6 months of service, he was supposed to be succeeded by a new superintendent who was chosen from the lay brethren. After the first 3 months of the initial superintendent's mandate, he would be flanked by the superintendent for the remaining 3 months of his tenure, so that the latter can learn the procedures and management methods required to fulfil his duties.

The 'Superintendent of the Sickness' received regular funding from the city of Florence, which was derived from various fines that were levied throughout the community and the Misericordia's own resources, with special emphasis on the alms received in the collection boxes. The overall funding for the treatment and prevention of the disease was not managed directly by the 


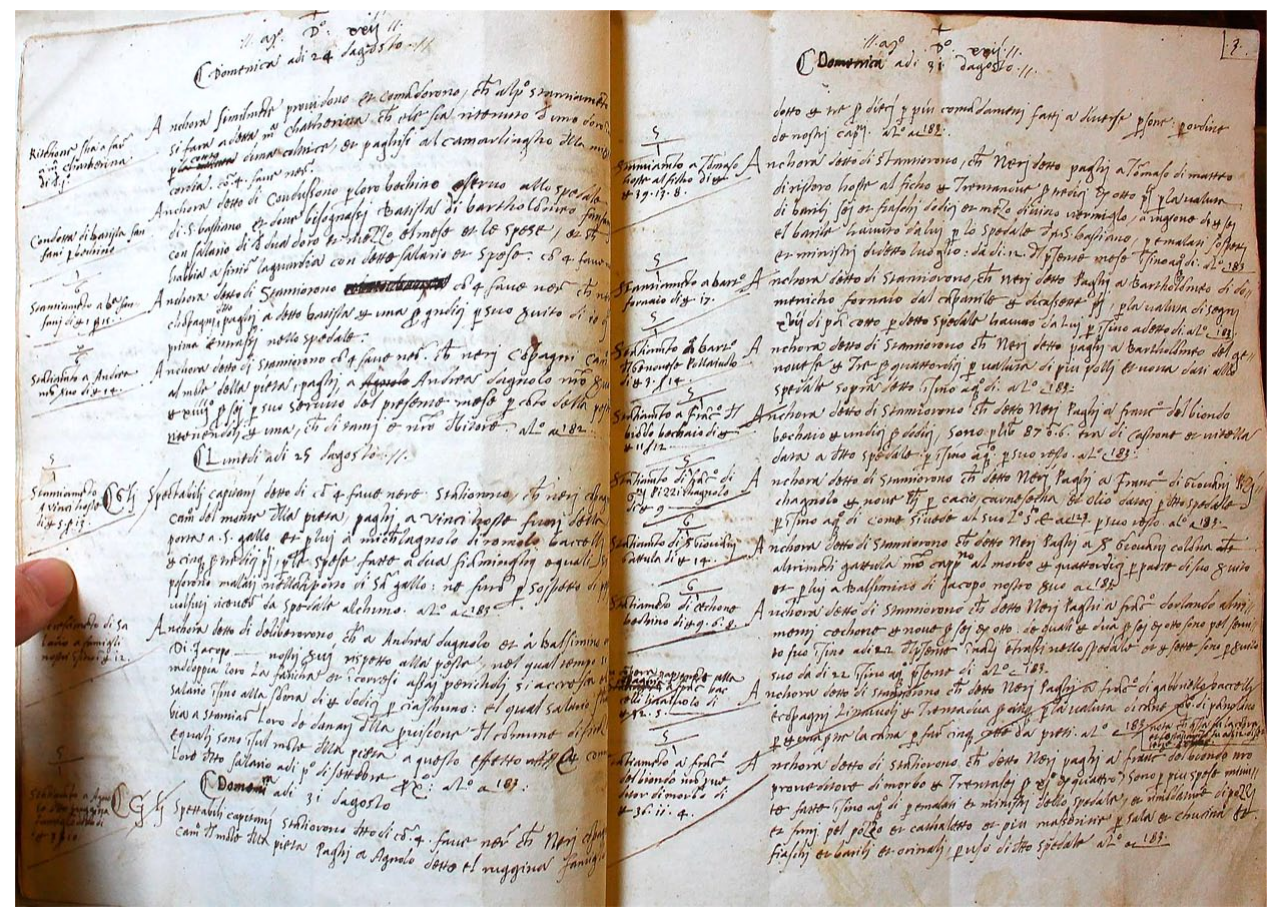

Figure I. Register of the superintendent.

AVamfi, Libro di partiti et stantiamenti di morbo, 1522-1524, Morini AA20II, cc. 2v-3r.

'Superintendent of the Sickness' but by a depositary chosen from representatives outside the Confraternity. By using the depositary as an external and independent trust, Misericordia signalled to its stakeholders its willingness to pursue policies emphasising transparency and to stress the importance of correctly managing funds and avoiding misconduct that could create conflict with the principles of the organisation.

The superintendent kept a register of about 60 pages, which had to be closed at the end of each quarter. It acted as a record of all incoming funds, including all monies withdrawn from the depositary and all food items purchased from the main suppliers (bakers, poultrymen, butchers, spice merchants and cheese and preserved meat sellers). Expenses included anything incurred by the plague sufferers, each of whom was given a separate account. Those who received assistance automatically became debtors to the Confraternity. Figure 1 shows two pages from the superintendent's register for the years 1522-1524.

The register was double-checked using a register of the depositary from the same period. Figure 2 includes two pages from a 1499 edition of the depositary's register.

This latter is usually entitled to the relative depositary with a sentence on the front page:

1499 [1500]. ${ }^{1}$ This revenues and expenses [register] is kept by the Brotherhood of Miserichordia of Florence that buries [the corpses]; it [the register] is kept for me, Tomaso di Giovanni Benini, the banker at Canto alla p[aglia], as Depositary of such fellowship, nominated by captains of such fellowship. The 12th of January 1499 [1500], so that I could start to take and give [money].

Incomes reported in the register were derived not only from the collection boxes of Domenicho, Landino, Balsimino and Pierobut also from alms and the city of Florence. Reported expenses 


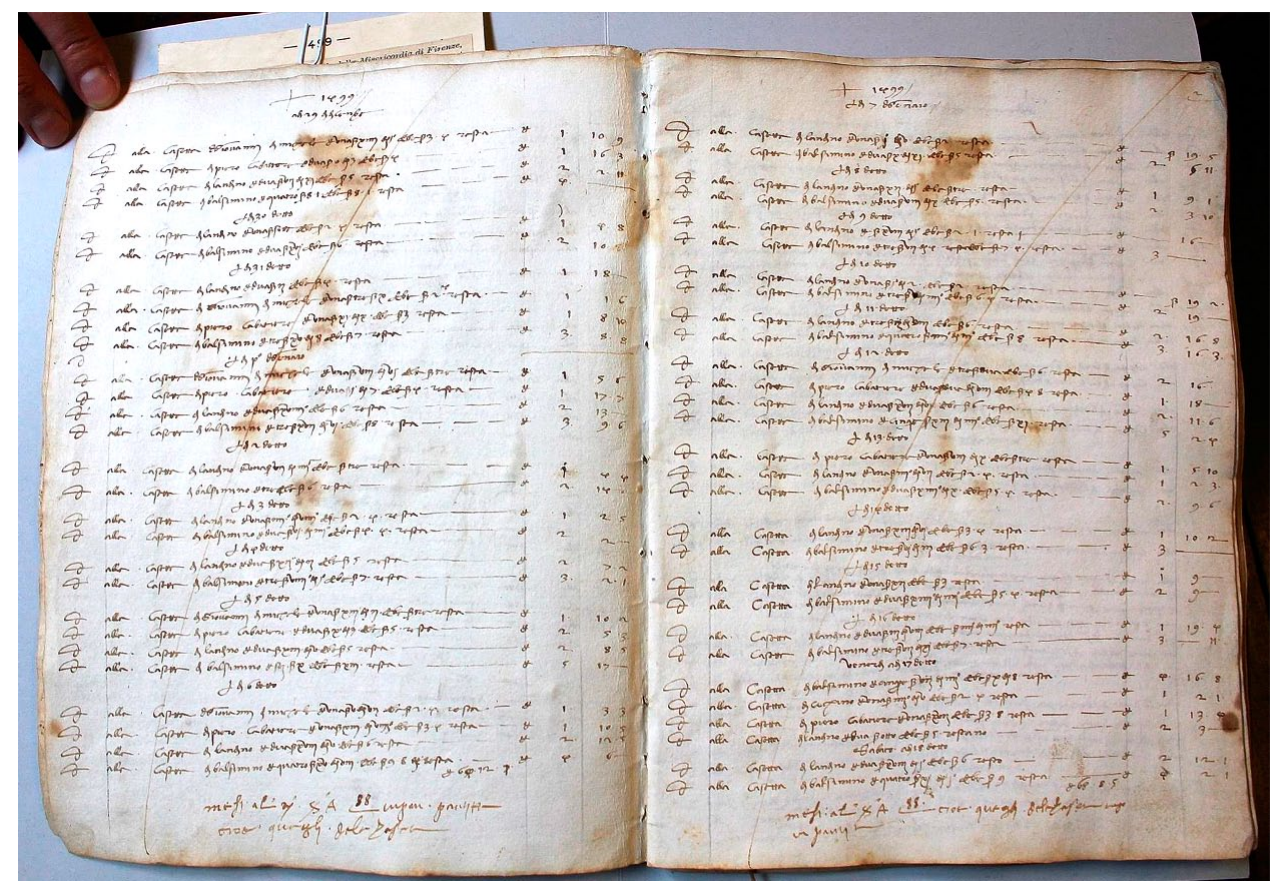

Figure 2. Register of the depositary.

AVamfi, Riscontro delle entrate e uscite del depositario - Entrate e uscite per la muraglia di San Christofano, 1499-1535, Morini I II I288, c. 88.

included wagesand rents; food and supplies, such as oil, eggs, meat and wheat; and other materials, such as sheets, candles and vinegar (which was used as disinfectant) that 'needed to be carried to the hospital to treat the ill people'. The following passage provides instructions on how a depositary's register is structured:

1520. Revenues and expenses registered by the depositary in chronological order. 'Debit' on the left page with Arabic numeration of papers; 'Credit' on the right page with Arabic numeration of papers.

All purchasing and allocation of funds were done quarterly and required the issuing of receipts (direct withdrawals could be made on the depositary but only for so-called petty cash transactions). In order to assure transparency, the depositary was required to issue the superintendent with a receipt whenever this happened. In the absence of a receipt, petty cash expenses were paid for directly by the depositary from his own funds; payment of the so-called ministers (e.g. physicians and nurses) was made monthly. Moreover, every supplier, whether tradesman or professional, was required to keep a record of purchases made by the superintendent to avoid allegations of misconduct. Once the new superintendent assumed office, the quarterly register must be closed and all amounts paid up, so that the new superintendent does not pay the debts or receive the credits contracted by his predecessor. An exception could be made if the captains gave explicit authorisation to the contrary.

The collection boxes were opened by the Superintendent of the Sickness in the presence of at least one captain and the depositary (or a person authorised by him), and the total amount was immediately consigned to the latter, and a receipt was issued. The depositary was expected to note 


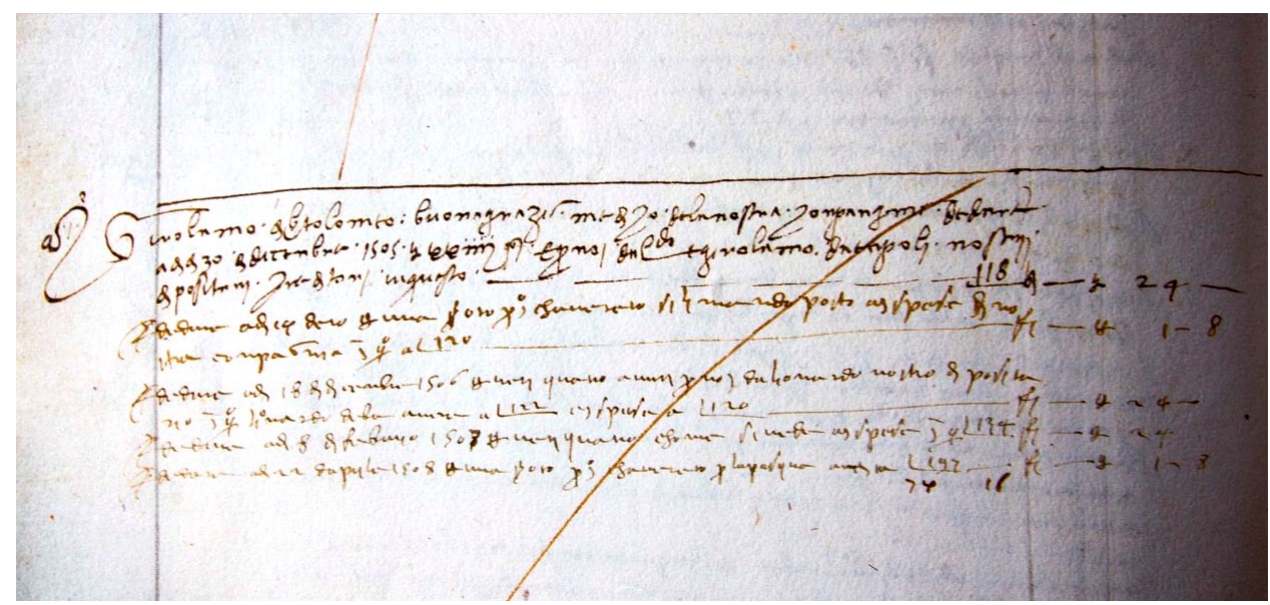

Figure 3. Double-check: detail of the payment to Buonagrazia in the debtors/creditors register of the superintendent (1522).

AVamfi, Appuntature e tasse; debitori e creditori - segnato C, I505-1516, Morini F380, c. II7.

in the register any money received by him apart from the tax levy (which came from the Republic) and charitable offerings, unless the sums arrived without a receipt and were immediately spent on assistance. The keys of the collection boxes were kept by the General Superintendent, the only person authorised to open and close them.

At the end of each quarter, the Superintendent of the Sickness made an inventory of available capital, which was then passed along to the next superintendent, who noted it on the first page of his new register. However, making an inventory was not compulsory if the amount of capital, at the end of the period, was less than 'fiorini uno larghi d'oro'. Figures 3 and 4 show details from a debtors/creditors register of the superintendent and an expenses/revenues register of the depositary that contains information about the annual payments from the physician Girolamo Buonagrazia (cf. section 'Sources'), including a goat for Easter.

To ensure transparent operations and compliance with the moral values that inspired the Confraternita, the provision of 1500 ruled that the offerings deposited in the collection boxes of the Misericordia should be emptied in the presence of at least one captain, the Superintendent of the Sickness and the Camerlingo of the Confraternity. This ruling became part of the statute of the Misericordia in 1501 (Torricelli et al., 2014).

The role of the Misericordia in managing the plague epidemic grew so rapidly that they also took on the management of the lazarettoof San Sebastiano in 1505, which was previously under the authority of the hospital of Santa Maria Nuova (Diana, 2014). Thus, the Misericordia effectively broadened its services and sphere of influence. Besides transporting the sick and burying the dead, it also became a vital manager of the plague health emergency on behalf of the Republic (Torricelli et al., 2014).

During the plague of 1522, the Misericordia was given 'global' management of the sick and everything needed for their care, including the lazarets (e.g. San Salvi); the structures to temporarily house those suspected of infection; supplies of food, water and medicine; and the construction of wooden huts outside the town walls to house those who were unable to receive treatment in hospitals (Cipolla, 1976; Diana, 1995). By the 1520s, the Misericordia was also given the task of persuading the sick to admit themselves to the hospital. 


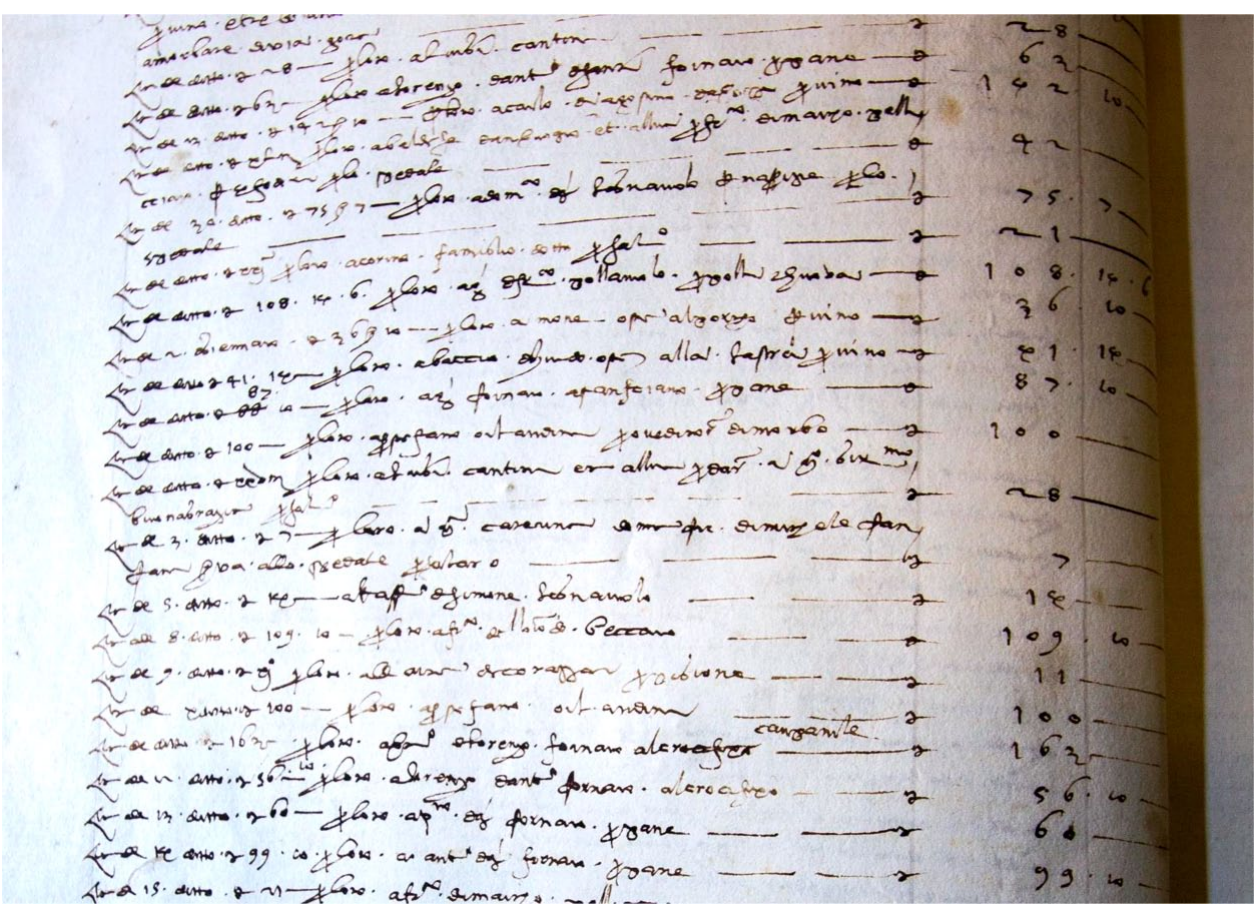

Figure 4. Double-check: detail of the payment to Buonagrazia in the expenses/revenues register of the depositary (1522).

AVamfi, Fratelli e sorelle del Numero maggiore e loro tasse/Congregazione detta del Numero maggiore con Entrate e uscite, 1522-1527; 1539, Morini E368, c. 2r.

However, the proactive role of the Confraternita was even wider. Sometimes, in the absence of relatives, the Misericordia paid someone to look after the sick person. Indeed, the Archives of Misericordia houses a rare revenues and expenses register in which it is noted that David Ghirlandaio, the brother of the famous painter Domenico Ghirlandaio, requested and obtained a subsidy in order to pay the maidservant who was taking care of his children and the children of his brother-in-law, Bastiano Mainardi: ${ }^{2}$

Davit di Tommaso del Grillandaio has to give on the 25 October [2013] ten lire for him at the servant Mea, and for us from Monte della Pietà, thus we promise him as a subsidy for taking care of the children of Bastiano [Mainardi], his brother in law (...).

In exchange for their considerable financial outlay, the Misericordia might count on donations left by the patient upon his death, which were oftentimes willed to the organisation.

The Misericordia also assumed responsibility for diffusing cultural and scientific information on the plague during the 1520s. In January 1522, for instance, a brother wrote a short treatise, with assistance from Girolamo Buonagrazia and other important physicians from Florence, on how to treat the illness (Affolter and Rossi, 2015; Morini, 1940: 126-133). The first 25 pages, which was written in Latin and was addressed to physicians, discussed precautions, diagnosis and treatment of the illness. The remaining 10 pages, which was written in the vulgar tongue and was addressed to non-medical assistants, discussed how to best support and aid the sick (Ficino, 1983: 55). In other words, the Republic recognised the competence of the Misericordia in providing assistance 
to plague sufferers and agreed that the best experts were already working for the Confraternity. Thus, in the lazaretof San Sebastiano alone, the Misericordia employed no less than five physicians in 1525 . In that same year, the Confraternity also began to recruit medical staff that could be called to address emergencies outside the town walls.

During yet another outbreak of plague between 1527 and 1528, shortly before the siege of Florence by the troops of Charles V (1529-1530), the dedicated work of the Misericordia reached its apex, thereby consolidating an operating structure that was based on specific legal and economic agreements with the Republic. As further proof of the inextricable connection between the social, political and religious context and the governmentality of Misericordia, these agreements were the bases for the health system of Cosimo I (who ruled Tuscany as Duke from 1537 to 1574) which was based on the Magistratura degli Ufficiali di Sanità.

The role of the Misericordia in managing plague emergencies drew to a close during the 1530s. The reasons were purely political: 1530 witnessed the end of the siege of Florence by Spanish and German troops that were sent by the Emperor, following the reconciliation between Clement VII and Charles V. The defence of the town featured contributions from Francesco Ferrucci and Michelangelo Buonarroti. In 1512, two years after the town fell, the Medici were restored under Alessandro de' Medici, who may have been the illegitimate son of Pope Clement VII. The return to power of the Medici family marked not only the end of the Republic and the start of the Duchy but also the need to re-centralise health services. Unfortunately, the functions of assistance that were so widely delegated to intermediate and independent bodies such as the Misericordia did not sit well with the centralising vision of the Duchy.

\section{Discussion}

All of the strategies that were employed by the Confraternita to assure transparency, avoid grievances and bring about compliance with the moral values of the Church represent some of the more peculiar characteristics of these accounting and reporting mechanisms. The previously mentioned systems of checks and balances guaranteed two important functions. First, they allowed the Misericordia to present itself to the Republic of Florence as an accountable organisation and as a charity capable of managing public funds for the poor without grievances. Second, since the Misericordia was inspired by religious values, these accounting systems permitted the organisation to present itself as being compliant with Church doctrine and policy.

The primary and secondary sources indicate that the decision to adopt a specific accounting and reporting system was inextricably connected to both internal factors (e.g. the Misericordia's religious values, members and operating methods) and external factors (e.g. the features and needs of the community in which the Confraternita operated). Thus, the complex statutory provisions were clearly motivated by the need to guarantee transparency in managing the money received by the Confraternity, preventing embezzlement by individuals and improving accountability to its stakeholders.

Moreover, it is also evident that a strong religious spirit led the various administrators to manage, with a sense of detachment and a spirit of giving, the monetary resources given to the Misericordia whenever the plague reappeared. According to Quattrone (2004) and Servalli (2013), the development of accountability practices in religious charities was linked to the Church's values and should not be considered solely as a mechanism of financial control. Indeed, the Confraternita monitored the flows of money closely for non-economic reasons as well. Since money was considered 'the devil's excrement' (Le Goff, 2010) during much of the Middle Ages, religious values deeply affected the management of resources. ${ }^{3}$ The plague, after all, was seen as a 'divine punishment' inflicted by the Lord for the great sins committed by His people. Therefore, it was the task 
of the brethren to follow God's will by assisting the sick in a spontaneous and freely given manner (Henderson, 1994). ${ }^{4}$ These types of views appear to confirm the presence of pressures on Misericordia members to adopt a management style that reinforced the organisation's religious values. This ruling became part of the statute of the Misericordia in 1501 (Torricelli et al., 2014).

At the same time, the Republic's decision that payments to the Captains of the Misericordia were not to be made directly by the town's camerlinghi, but rather by the camerlingo of the Florentine 'mount of piety', can be interpreted as further confirmation of the strong influence of religious values in the management of financial resources (cf. Quattrone, 2004). The accounting system adopted by the Misericordia in Florence at the beginning of the sixteenth century illustrates how accounting practices are often driven by regulative, normative and cognitive factors that are related to specific social contexts. Political, social, religious and organisational norms all helped shape the accounting system that would eventually be adopted while taking care of plague victims.

These norms are also consistent with Foucault's concept of 'governmentality', as all of these accounting and control mechanisms represent an efficient form of social control by the Confraternita, which expected compliance with Church doctrine and policy. The Confraternita adopted organised methods of sick relief in which public authority and the charity itself operated as partners in a 'government of the poor', adopting a host of 'ad hoc' technologies (Miller and Rose, 1990: 8; see also Servalli, 2013). This included the building of lazarets (e.g. San Salvi) for temporarily housing those suspected of infection; supplying food, drink and medication to those who remained at home without the assistance of relatives; and the construction of wooden huts outside the town walls to house those who were unable to receive treatment in hospitals, thereby preventing vagrancy, begging and further spread of the plague. In this context, lazarets, wooden huts and other sites of social authority, regulation and control can be interpreted as noteworthy examples of a 'technological threshold of force' (Dean, 1996).

This is part of a complex system of practical rationalities and technologies of government. Public authorities contributed to this process by creating a commission known as 'the Officials of the Sickness' in 1496, an organisation that was given the task of managing the emergency according to the provision signed with the Misericordia in 1499, and agreeing to make periodic payments that were levied by the town's chamberlains. The Officials of the Sickness, the Superintendent of the Sickness, and, by extension, the Magistratura degli Ufficiali di Sanità can be interpreted as examples of 'thresholds of the orientation of government', as they are figures or organisations that improve and optimise the forces and capabilities of other groups or subjects (Dean, 1996). The Confraternita, meanwhile, contributed to this process by establishing non-financial and financial systems of accounting, reporting and oversight. Non-financial information often referred to the care of people affected by the plague and other material pertaining to the delivery of food and medication. This included lists of sick people who received assistance, food and medication suppliers; the Confraternity's debtors; and the register of suppliers for purchases made by the superintendent.

According to Dean (1996: 63), financial and non-financial information can be understood as 'technological thresholds' because they are forms of government technology. Financial information included a wide variety of books, registers and documents, such as the register of the payments made by the camerlingo of the mount of piety, the registers of the superintendent and the depositary, the list of expenses, the receipts of purchases made and the receipts issued by the depositary for 'petty cash transactions'. The superintendent's register; the Misericordia's statute; and, in a broad sense, even the short scientific treatise on the plague that was written in 1522 represent examples of system thresholds, as they are tools that influence the relationship between the technology of government and other kinds of technologies that affect the provision of services, consumption and communication. 
The Republic of Florence sought to affirm its role as a governing body by entrusting the relief and assistance services of sick people to the Confraternita of Misericordia. Various forms of oversight were adopted in order to prevent inefficient use of resources, fraud and misconduct. The provision signed between the Republic of Florence and the Misericordia was an attempt to police the poor by ensuring that the charity acted as a fundamental agency in the community (Minson, 1985: 104-105). All the agreements signed between the Republic of Florence and the Misericordia of Florence, including the various provisions and related arrangements concerning the collection of levies, can be interpreted as examples of Dean's 'threshold of assemblage' and 'practical rationalities' (cf. Servalli, 2013), since they are policies that reflect the willingness of both the Republic and the Church to maintain the social and economic order.

Since policing is often seen as an 'ensemble of mechanisms serving to ensure order, the properly channeled growth of wealth and the conditions of preservation of wealth "in general", (Foucault, 1984b: 277), we believe that the management of the plague in Florence during the first few decades of the Renaissance represented a concerted attempt to police the poor. In an era when the population was struck hard by disease, the Confraternita, as a partner and service provider for the Republic of Florence, was essential for supporting sick people, especially poor families.

The Republic and the Church, although they were considered independent entities, often operated in concert to police the poor. The combined powers of the Church and the Republic were used to control the population, influencing daily life, including a wide range of health-care issues. If there is no doubt that religion played a fundamental role in shaping the management of resources, it can be assumed that policing the poor was practised by both the Church and the Republic, both of which were heavily influenced by wealthy families and high-ranking artisans, merchants and bankers.

According to Servalli (2013), assistance to the poor in Italy began to assume new features during the modern era, as poor relief was not necessarily being led by religious people. The results of our research seem to suggest that the Confraternita of Misericordia played a fundamental role in providing public assistance to poor and sick people in the Republic of Florence.

\section{Conclusion}

Drawing on archival evidence, this article interpreted the conditions that led the Confraternita of Misericordia to develop a specific system of accountability at the end of the fifteenth century. Our primary and secondary sources provide us with a glimpse into the complex administrative and accounting mechanisms that were established by the Misericordia to ensure transparency and compliance with the rules for managing resources during the various plague epidemics that took place between 1490 and 1530 .

Our historical analysis helps explain how religious values, political environments, rules and norms, mechanisms of contracting-out public services and accounting practices are interconnected (Ball and Craig, 2010). Politicians associated with the Republic of Florence recognised that the Misericordia was uniquely suited to handle the plague emergency, while also noting that specific agreements were necessary before the partnership could be officially recognised. In this instance, the local religious community asked for transparency in order to guarantee that offerings collected in church and other donations were actually used to heal the sick. At the same time, the Confraternita needed to create a set of accountability practices that was capable of measuring, managing and allocating resources in such a way as to comply with prevalent religious values. These intertwined requirements explain why accounting and accountability practices were not conceived as merely tools for efficiently measuring and allocating resources but were seen as expressions of various religious and political factors. 
We have discussed how the Misericordia's accounting techniques should be seen as 'technologies of government' and 'technological thresholds'. Foucault's and Dean's ideas on how various institutions police the poor find expression in our sources. During the Middle Ages and the first decades of Renaissance, diverse policing agencies, including charities inspired by faith, were given the task of assuring order and providing financial assistance to the poorest parts of society. Financial and non-financial accounting information was considered part of the complex set of technologies that were used to govern the poor (Servalli, 2013).

The accounting records and hierarchical structure of charitable organisations such as the Misericordia illustrate the continuous process of compromise that came to be affected by theological, political, institutional, economic and social pressures (Quattrone, 2004; Servalli, 2013). Various brotherhoods became rich and powerful during the Renaissance, but their religious principles required them to handle money with caution and detachment and to use it exclusively to help the poor and the sick. In the case of Misericordia, this was confirmed by the creation of a new statute that devoted an entire chapter to the plague (chapter XVI Quando fussi tempo di morbo) in which this terrible illness was seen as a form of divine punishment. This complex and innovative accounting system, whose rules are clearly introduced in the Misericordia's statute of 1501, emphasised double-checking between different registers and continuously tracing the flow of money. This accounting system offered internal and external stakeholders a measure of accountability and legitimisation and was conceived by the Misericordia to comply not only with external calls for efficiency and transparency but also to comply with the religious values that inspired it. This confirms that accounting and accountability practices cannot be conceived along one-dimensional lines, be they economic or religious in nature (Quattrone, 2004), but rather represent a process marked by compromise among several different social and cultural forces.

We believe that this study contributes to the accounting history literature by examining relatively unexplored topics, such as the role of NPOs in the administration of health care and poverty during the first decades of the Renaissance, the role of charities in providing 'public services' for the poor and the utilisation of accounting measures as control mechanisms in accordance with religious values and norms. Our examination of select historical documents allowed us to explain how a sound, tailored and customised accounting system played an active role in avoiding conflict and efficiently responding to religious, political, institutional and economic pressures during the early parts of the Renaissance. The Misericordia's attempts to maintain order in the community and assist the poor also confirms Foucault's ideas on 'governmentality', 'policing' and 'power' (Foucault, 2010).

Furthermore, the relationship between the Republic of Florence and the Misericordia, as well as the political and accounting mechanisms that were set up to effectively support the contracting out of various health services at the beginning of the sixteenth century, illustrates how the values and principles of subsidiarity, plurality and inclusion were being applied during the early decades of the Renaissance. The Misericordia's partnership with the Republic is an early example of how a local institution could use its expertise to provide assistance to those in need and, at the same time, ensure a responsible accountability mechanism that was both fair and prevented criticism. The emphasis on transparency and the inclusion of various rules to avoid corruption, misconduct, grievances and misappropriation shows that this accounting system worked well in a partnership that was created in order to provide the community with a wide range of public services.

The results of this study show that the role of charities during the first decades of the Renaissance, together with the use of government technologies or technological thresholds (e.g. the accounting practices implemented by the Misericordia), represent a significant opportunity for further research from both a diachronic and synchronic perspective. The role played by charities - especially charities that were inspired by religious values - in this historical context points out the need for further historical investigation in this field in order to better understand the characteristics of charity 
services and interventions in partnership with the local authorities. Accountability practices should be carefully investigated in both the context of charities and local public authorities in order to highlight their role as a 'technology of government' within the 'government of the poor'.

\section{Acknowledgements}

We wish to thank the Misericordia of Florence for opening the doors of its historical archive to us. We are particularly grateful to Barbara Maria Affolter and Laura Rossi for their kind and competent advice, which has played a fundamental role in how we interpreted the historical documents presented in this article. We are also grateful to the two anonymous reviewers and the Editor of Accounting History for their valuable suggestions in improving this article. Although this article is the result of a team effort, Giacomo Manetti can be considered the author of sections 'Introduction', 'Theoretical framework' and 'The origins of the Misericordia in Florence'; Marco Bellucci the author of sections 'Sources', 'Misericordia and accounting for the plague' and 'Discussion'; and Luca Bagnoli the author of section 'Conclusion'.

\section{Funding}

The author(s) received no financial support for the research, authorship and/or publication of this article.

\section{Notes}

1. The modern date using the Gregorian Calendar can be found in square brackets.

2. Bastiano Mainardi (1460-1513) was an Italian painter born in San Gimignano (Siena). Domenico Ghirlandaio was his brother-in-law and master.

3. A popular symbolic representation of money in the medieval iconography is a heavy bag that hangs from the neck of a rich person and drags him to hell (Le Goff, 2010).

4. In The Decameron, Bocaccio (1903) describes the plague as inevitable, as being 'sent upon us mortals by God in His just wrath by way of retribution for our iniquities' (p. 69).

\section{References}

Affolter BM and Rossi L (2015) De provisione et cura morborum pestilentialium. Hieronimi De Bonagratiis, Physici Florentini. Firenze: Misericordia di Firenze.

Arbid L (1838) Storia fiorentina di Benedetto Varchi. Milano: Società Tipografica.

Ball A and Craig R (2010) Using neo-institutionalism to advance social and environmental accounting. Critical Perspectives on Accounting 21(4): 283-293.

Bargellini P (1980) La splendida storia di Firenze. Firenze: Vallecchi.

Bianchi C (1855) La Compagnia della Misericordia. Firenze: Cenni storici.

Black CF (1989) Italian Confraternities in the Sixteenth Century. New York: Cambridge University Press.

Boccaccio G (1903) The Decameron (trans. JM Rigg). London: The Navarre Society.

Booth P (1993) Accounting in churches: A research framework and agenda. Accounting, Auditing \& Accountability Journal 5(4): 37-67.

Brucker GA (1998) Florence: The Golden Age 1138-1737. Oakland, CA: University of California Press.

Bryman A and Bell E (2015) Business Research Methods. New York: Oxford University Press.

Carmichael AG (1986) Plague and the Poor in Renaissance Florence. Cambridge: Cambridge University Press.

Cipolla CM (1976) Public Health and the Medical Profession in the Renaissance. Cambridge: Cambridge University Press.

Cohen M (2005a) Feeding the poor and clothing the naked: The Cairo Geniza. Journal of Interdisciplinary History 35(3): 407-421.

Cohen M (2005b) Poverty and charity in past times: Judaism, Christianity, and Islam. Journal of Interdisciplinary History 35(3): 347-360.

Corbellini S and Hoogvliet M (2013) Artisans and religious reading in late medieval Italy and Northern France (ca. 1400-ca. 1520). Journal of Medieval and Early Modern Studies 43(3): 521-544. 
Corsini A (1911) La 'Moria' del 1464 in Toscana e l'istituzione dei primi lazzaretti in Firenze ed in Pisa: communicazione fatta alla Società Toscana d'Igiene nell'adunanza del 26 Maggio 1911. Firenze: Tipografia e Libreria Claudiana.

Critchlow DT and Parker CH (1998) With Us Always: A History of Private Charity and Public Welfare. Lanham, MD: Rowman \& Littlefield Publishers.

Dean M (1991) The Constitution of Poverty: Toward a Genealogy of Liberal Governance. London: Routledge.

Dean M (1992) A genealogy of the government of poverty. Economy and Society 21(3): 215-251.

Dean M (1996) Putting the technological into government. History of the Human Sciences 9(3): 47-68.

Della Stufa S (1528) Discorso della peste dell'anno 1522 e 1528. Firenze: Biblioteca Nazionale Centrale di Firenze.

Di San Luigi I (1786) Istorie Di Giovanni Cambi Cittadino Fiorentino V4 (1786). Firenze: Biblioteca Nazionale Centrale di Firenze.

Diana E (1995) Sanità nel quotidiano: Storie minute di medici, cerusici e pazienti. Firenze: Pugliese.

Diana E (2014) La sanità delle origini: così nacque l'assistenza. In: VVAA (eds) Misericordia di Firenze 1244-2014, 770 anni della Misericordia di Firenze. Firenze: Edizioni Polistampa, pp. 1-32.

Donnelly JP and Maher MW (1999) Confraternities and Catholic Reform in Italy, France \& Spain. Kirksville, MO: Truman State University Press.

Eckstein NA (2004) Words and deeds, stasis and change: New directions in Florentine devotion around 1500. Journal of Religious History 28(1): 1-18.

Elden S (2003) Plague, panopticon, police. Surveillance \& Society 1(3): 240-253.

Ficino M (1983) Consilio contro la pestilenza. Bologna: Florenza.

Fleischman RK and Tyson TN (1997) Archival researchers: An endangered species? The Accounting Historians Journal 24(2): 91-110.

Fouarge D (2004) Poverty and Subsidiarity in Europe: Minimum Protection from an Economic Perspective. Northampton: Edward Elgar.

Foucault M (1984a) Space, knowledge, and power. In: Rabinow P (ed) The Foucault Reader. New York: Pantheon Books, pp. 239-256.

Foucault M (1984b) The politics of health in the eighteenth century. In: Rabinow P (ed) The Foucault Reader. New York: Pantheon Books, pp. 273-290.

Foucault M (1991) Governmentality. In: Burchell G, Gordon C and Miller P (eds) The Foucault Effect: Studies in Governmentality. Hemel Hempstead: Wheatsheaf Publications, pp. 87-104.

Foucault M (2007) Notes. In: Davidson AI (ed.) Security, Territory, Population: Lectures at the Collège de France 1977-1978. New York: Palgrave Macmillan, pp. 1-35.

Foucault M (2010) The Government of Self and Others: Lectures at the Collège de France 1982-1983. New York: Palgrave Macmillan.

Gaffikin M (2011) What is (accounting) history? Accounting History 16(3): 235-251.

Gazzini M (2012) Solidarity and brotherhood in medieval Italian confraternities: A way of inclusion or exclusion? Reti Medievali Rivista 13(2): 109-120.

Golinelli P (1984) La Pataria: Lotte religiose e sociali nella Milano dell'xi secolo. Milano: Europìa-Jaca Book.

Henderson J (1987) Epidemie nella Firenze del rinascimento: teoria sanitaria e provvedimenti governativi. In: Pastore A and Sorcinelli P (eds) Sanità e Società. Emilia-Romagna, Toscana, Marche, Umbria, Lazio. Udine: Casamassima, pp. 49-60.

Henderson J (1994) Piety and Charity in Late Medieval Florence. Oxford: Oxford University Press.

Kelly M and O'Gráda C (2011) The poor law of old England: Institutional innovation and demographic regimes. Journal of Interdisciplinary History 41(3): 339-366.

Le Goff J (2010) Lo sterco del diavolo: il denaro nel Medioevo. Bari: Economica Laterza.

Lee EK (2005) Art and ritual drama of the flagellant confraternities in 13th-15th century Italy. Arte Medievale 4(2): 69-81.

Lemke T (2001) 'The birth of bio-politics': Michel Foucault's lecture at the Collège de France on neo-liberal governmentality. Economy and Society 30(2): 190-207. 
Little LK (1988) Libertà, carità, fraternità: confraternite laiche a Bergamo nell'età del comune. Bergamo: Lubrina.

McIntosh MK (2005) Poverty, charity, and coercion in Elizabethan England. Journal of Interdisciplinary History 35(3): 457-479.

Merlo GG (1984) Pietro da Verona-S. Pietro Martire. Difficoltà e proposte per lo studio di un inquisitore beatificato. In: Boesch Gajano S and Sebastiani L (eds) Culto dei santi: istituzioni e classi sociali in età preindustriale. Roma: L.U. Japadre, pp. 471-488.

Miller P and Rose N (1990) Governing economic life. Economy and Society 19(1): 1-31.

Minson J (1985) Genealogies of Morals: Nietzsche, Foucault, Donzelot and the Eccentricity of Ethics. London: Palgrave Macmillan.

Morini U (1940) Documenti inediti o poco noti per la storia della Misericordia di Firenze (1240-1525). Firenze: Arciconfraternita della Misericordia.

Munslow A (2007) Narrative and History. Basingstoke: Palgrave Macmillan.

Najemy JM (2008) A History of Florence 1200-1575. Oxford: Blackwell Publishing.

Paglia V (1984) Jubilaum Internationale Confraternitatum. Roma: Acta.

Parker L (1999) Historiography for the new millennium: Adventures in accounting and management. Accounting History 4(2): 11-42.

Pesman Cooper R (1967) L'elezione di Pier Soderini a gonfaloniere a vita. Note storiche. Archivio Storico Italiano 454(CXXV): 125.

Quattrone P (2004) Accounting for god: Accounting and accountability practices in the society of Jesus (Italy, 16th-17th centuries). Accounting, Organizations and Society 29(7): 647-683.

Riccaboni A, Giovannoni E, Giorgi A and Moscadelli S (2006) Accounting and power: Evidence from the fourteenth century. Accounting History 11(1): 41-62.

Rose N and Miller P (1992) Political power beyond the state: Problematics of government. British Journal of Sociology 43(2): 174-205.

Sargiacomo M and Gomes D (2011) Accounting and accountability in local government: contributions from accounting history research. Accounting History 16(3): 253-290.

Servalli S (2013) The interface of power and charity in the government of poor. Accounting, Auditing \& Accountability Journal 26(8): 1306-1341.

Tombaccini D (2009) Florence and Its Hospitals: A History of Health Care and Assistance in the Florentine Area. Florence: Florence University Press.

Torricelli C (2014) 770 anni della Misericordia di Firenze. In: Rossi L, Affolter BM, Santini E, et al. (eds) Una sconfinata Carità 1244-2014. Firenze: Edizioni Polistampa, pp. 33-67.

Torricelli C, Lopes Pegna M, Danti M and Checcucci O (1975) La Misericordia di Firenze attraverso i secoli. Firenze: Misericordia.

Van Leeuwen M (1994) Logic of charity: poor relief in preindustrial Europe. Journal of Interdisciplinary History 24(4): 589-613.

Weissman RFE (1982) Ritual Brotherhood in Renaissance Florence. New York: Academic Press. 